\title{
Evidence for an Intramedullary Prostaglandin-Dependent Mechanism in the Activation of Stress-Related Neuroendocrine Circuitry by Intravenous Interleukin-1
}

\author{
A. Ericsson, ${ }^{2}$ C. Arias, ${ }^{1}$ and P. E. Sawchenko ${ }^{1}$ \\ ${ }^{1}$ Laboratory of Neuronal Structure and Function, The Salk Institute, La Jolla, California 92037, and 2Unit of Rheumatology, \\ The Karolinska Hospital, S-171 76 Stockholm, Sweden
}

\begin{abstract}
We have provided evidence that the stimulatory effects of intravenous interleukin-1 (IL-1) on neurosecretory neurons in the paraventricular nucleus (PVH) that express corticotropinreleasing factor (CRF) depend specifically on the integrity of catecholaminergic projections originating in caudal medulla. Here we report on experiments designed to test alternative means by which circulating IL-1 might access medullary aminergic neurons, including mechanisms involving sensory components of the vagus, the area postrema, or perivascular cells bearing IL-1 receptors. Neither abdominal vagotomy nor area postrema lesions reliably altered Fos expression induced in the medulla or $\mathrm{PVH}$ in response to a moderately suprathreshold dose of IL-1 $\beta$. Cytokine-stimulated increases in CRF mRNA in the PVH were also unaffected by either ablation. By contrast, systemic administration of the cyclooxygenase inhibitor indomethacin resulted in parallel dose-related attenuations of IL-1
\end{abstract}

effects in hypothalamus and medulla. Microinjections of prostaglandin E2 (PGE2; $\geq 10 \mathrm{ng}$ ) in rostral ventrolateral medulla, the principal seat of IL-1-sensitive neurons that project to the $\mathrm{PVH}$, provoked discrete patterns of cellular activation in hypothalamus and medulla that mimicked those seen in response to intravenous IL-1. We interpret these findings as supporting the hypothesis that paracrine effects of PGE2 released from perivascular cells in the medulla as a consequence of IL-1 stimulation and, acting through prostanoid receptors on or near local aminergic neurons that project to the $\mathrm{PVH}$, contribute to the stimulatory effects of increased circulating IL-1 on neurons constituting the central limb of the hypothalamo-pituitaryadrenal axis.

Key words: catecholamine neurons; corticotropin-releasing factor; hypothalamo-pituitary-adrenal axis; interleukin-1; neuroimmune interactions; paraventricular nucleus; prostaglandins
Representative of the bidirectional nature of interactions between the immune nervous system and the CNS are phenomena involving the hypothalamo-pituitary-adrenal (HPA) axis. The capacity of glucocorticoids, the end products of the HPA cascade, to inhibit immune and inflammatory responses broadly (Sternberg and Wilder, 1993) has been exploited clinically for decades (Hench et al., 1949). More recently it has been established that certain cytokines, particularly interleukin-1 (IL-1), can potently stimulate HPA activity (Besedovsky et al., 1975; Berkenbosch et al., 1987; Sapolsky et al., 1987; Harbuz et al., 1992). This has been taken as indicating a co-opting of a neuroendocrine mechanism by the immune system to regulate its own activity negatively, that is, to restrain excess cytokine production and immune cell proliferation after infectious or inflammatory episodes (Besedovsky et al., 1986). Dysfunction of this regulatory arm has been implicated in certain autoimmune disorders (Wick et al., 1993).

Stimulation of HPA output by IL-1 is mediated principally through parvocellular neurosecretory neurons that express corticotropin-releasing factor (CRF) and impart central drive to

\footnotetext{
Received March 6, 1997; revised July 1, 1997; accepted July 7, 1997.

This work was supported by National Institutes of Health Grant NS-21182 and was conducted in part by the Foundation for Medical Research. P.E.S is an Investigator of the Foundation for Medical Research. During the initial phases of this work, A.E. was supported by a Fogarty Foundation Fellowship and now is supported by grants from the Swedish Medical Research Council and the Swedish Society of Medicine. We thank Kris Trulock and Belle Wamsley for excellent assistance in the preparation of the illustrations and manuscript, respectively.

Correspondence should be addressed to Dr. P. E. Sawchenko, The Salk Institute, P.O. Box 85800, San Diego, CA 92186-5800.

Copyright (C) 1997 Society for Neuroscience $0270-6474 / 97 / 177166-14 \$ 05.00 / 0$
}

pituitary-adrenal output (Berkenbosch et al., 1987; Sapolsky et al., 1987; Rivest and Rivier, 1991). But the fact that IL-1 is a 17.5 $\mathrm{kDa}$ protein, which would not be expected to traverse the bloodbrain barrier freely, poses questions as to how it might access central HPA regulatory systems. Mechanisms involving entry at circumventricular organs, transduction by peripheral nerves, cytokine-receptor interactions at one or more of the brain-fluid interfaces with consequent release of local signaling molecules, and facilitated transport across the barrier, which might allow direct or afferent-mediated access to the endocrine hypothalamus, have been considered as a basis for such interactions (for review, see Dantzer, 1994; Watkins et al., 1995; Ericsson et al., 1996).

We have used immediate-early gene (IEG) technology (Morgan and Curran, 1991) to characterize the time- and dosedependent patterns of cellular activation in the rat CNS after intravenous administration of IL- $1 \beta$. A moderately suprathreshold dose of this cytokine preferentially activates CRF-producing neurosecretory neurons and medullary catecholaminergic neurons that project to them (Ericsson et al., 1994). The integrity of this pathway was shown to be specifically required for the IL-1mediated activation of CRF neurons and upregulation of CRF mRNA (Ericsson et al., 1994; Li et al., 1996). Complementary studies revealed a preferential expression of the type 1 IL-1 receptor (IL-1R1) in non-neuronal cells associated with barrier functions and in the area postrema (Cunningham et al., 1992; Wong and Licinio, 1994; Yabuuchi et al., 1994; cf. Ericsson et al., 1995a). The only CNS sites found to exhibit both IL-1 sensitivity and IL-1R1 expression were perivascular cells and the area 
postrema (Ericsson et al., 1995a). In view of the established role of medullary catecholaminergic neurons in processing visceral sensory information, these findings suggested three possible mechanisms by which increased circulating IL-1 may influence aminergic neurons, and, consequently, their hypothalamic targets: (1) peripheral transduction by visceral sensory nerves, particularly the vagus, which has been implicated as mediating endotoxin or IL-1 effects on HPA output under certain conditions (Wan et al., 1994; Gaykema et al., 1995; Kapcala et al., 1996); (2) transduction by the area postrema, a circumventricular structure, the major projections of which access medullary aminergic cell groups quite directly (Cunningham et al., 1994); or (3) transduction by perivascular cells, which can synthesize and release local signaling molecules, such as prostaglandins, with the capacity to modulate neuronal transmission via paracrine influences (e.g., Katsuura et al., 1988; Van Dam et al., 1993; Scammell et al., 1996; Elmquist et al., 1997). We report here the results of experiments designed to test these alternative mechanisms.

\section{MATERIALS AND METHODS}

\section{Animals}

Adult male Sprague Dawley albino rats (280-350 gm) were used throughout. Rats were housed individually in a temperature-controlled room on a $12 \mathrm{hr}$ light/dark cycle (lights on at 6 A.M.), with food and water freely available, and were adapted to handling for 1 week before any manipulation.

\section{Intravenous administration of $I L-1 \beta$}

Recombinant human IL- $1 \beta$ was generously provided by Dr. S. Gillis (Immunex, Seattle, WA). This protein corresponds to the 152 residue mature form of IL-1 $\beta$ and had an original specific biological activity in excess of $1 \times 10^{5} \mathrm{U} / \mu \mathrm{g}$ protein [A375 assay (Nakano et al., 1988); $17 \mathrm{pg}$ of endotoxin $/ \mu \mathrm{g}$ of protein]. On receipt, the material was thawed on ice, diluted 1:1 in $200 \mathrm{~mm}$ Tris- $\mathrm{HCl}$ buffer, $\mathrm{pH} 7.4$, at $25^{\circ} \mathrm{C}$, containing $0.2 \%$ $\mathrm{BSA}$, aliquoted in $1.5 \mu \mathrm{g}$ batches, and refrozen at $-70^{\circ} \mathrm{C}$. Thawed aliquots of IL- $1 \beta$ were stored at $4^{\circ} \mathrm{C}$ for no longer than $3 \mathrm{~d}$.

The procedure for systemic administration of IL- $1 \beta$ to rats has been described (Ericsson and Sawchenko, 1993). Briefly, methoxyfluraneanesthetized rats were implanted with indwelling jugular venous catheters (PE-50) containing sterile, pyrogen-free heparin-saline $(500 \mathrm{U} / \mathrm{ml})$; the sealed catheter was positioned with its internal SILASTIC (Dow Corning) tip at the atrium and was exteriorized at an interscapular position. After $2 \mathrm{~d}$ recovery, each experimental animal was connected in its home cage to a remote saline-filled catheter between 6 and 7 A.M. and $1.87 \mu \mathrm{g} / \mathrm{kg} \mathrm{IL}-1 \beta, 1.87 \mu \mathrm{g} / \mathrm{kg}$ heat-inactivated IL $-1 \beta\left(70^{\circ} \mathrm{C}\right.$ for $\left.30 \mathrm{~min}\right)$, or vehicle alone was delivered $2 \mathrm{hr}$ later in a total volume of $300 \mu \mathrm{l}$ over $3 \mathrm{~min}$ at $3 \mathrm{hr}$ before anesthetization and perfusion. The final composition of the vehicle was kept constant at $0.01 \%$ BSA, $0.01 \%$ ascorbic acid, 10 $\mathrm{mm}$ Tris- $\mathrm{HCl}, 36 \mathrm{~mm}$ sodium phosphate buffer, $\mathrm{pH} 7.4$, at $25^{\circ} \mathrm{C}$. Brains were harvested after perfusion fixation performed between 12:30 and 2 P.M., to minimize any complicating effects of diurnal variations in HPA axis activity.

\section{Tissue processing and histology}

Animals were deeply anesthetized with chloral hydrate $(35 \mathrm{mg} / \mathrm{kg}$, i.p.) and perfused via the ascending aorta with saline followed by $500-700 \mathrm{ml}$ of $4 \%$ paraformaldehyde in $0.1 \mathrm{~m}$ borate buffer, $\mathrm{pH} 9.5$, at $10^{\circ} \mathrm{C}$. Brains were post-fixed for $3 \mathrm{hr}$ and then cryoprotected in $10 \%$ sucrose in $0.1 \mathrm{M}$ phosphate buffer overnight at $4^{\circ} \mathrm{C}$. Five one-in-five series of $30-\mu \mathrm{m}$-thick frozen frontal sections through either whole brain or medulla and hypothalamus were collected in cold cryoprotectant $(0.05 \mathrm{M}$ sodium phosphate buffer, $30 \%$ ethylene glycol, and $20 \%$ glycerol) and stored at $-20{ }^{\circ} \mathrm{C}$ until histochemical processing. Series of sections destined for in situ hybridization histochemistry alone were further post-fixed in phosphatebuffered $4 \%$ paraformaldehyde overnight at $4{ }^{\circ} \mathrm{C}$ before being transferred to cryoprotectant for storage.

\section{Immunohistochemistry}

Immunohistochemical detection of Fos immunoreactivity (Fos-ir) was performed using an affinity-purified polyclonal antiserum raised in rabbit against a synthetic peptide corresponding to residues $4-17$ of the $\mathrm{N}$-terminal portion of the human Fos protein (Oncogene Sciences). This antiserum displays no known cross-reactivity with any identified Fosrelated antigens. Analysis for Fos-ir in was performed on free-floating sections using a conventional avidin-biotin-immunoperoxidase technique (Sawchenko et al., 1990). This included pretreating sections for 10 min each in $0.3 \%(\mathrm{v} / \mathrm{v})$ hydrogen peroxide and in $1.0 \%(\mathrm{w} / \mathrm{v})$ borohydride, with interposed rinses. Sections were incubated with the primary antiserum at a dilution of 1:7500. The primary antiserum was localized using Vectastain Elite reagents, and the reaction product was developed on ice using a nickel-enhanced glucose oxidase method (Shu et al., 1988). The specificity of the primary antiserum was confirmed in control experiments in which preadsorption of the antiserum overnight at $4^{\circ} \mathrm{C}$ with 50 $\mu \mathrm{M}$ synthetic immunogen eliminated basal and induced nuclear staining. The number of Fos-ir nuclear profiles was counted visually under $250 \times$ magnification in complete series of coronal sections through cell groups of interest, including the nucleus of the solitary tract (NTS), the ventrolateral medullary reticular formation (VLM) from the level of the caudal pole of the facial motor nucleus to the spinal-medullary transition area, and the medial parvocellular part of the PVH (Swanson and Kuypers, 1980), where hypophysiotropic CRF-expressing neurons are concentrated. Estimates were corrected for double-counting errors using the method of Abercrombie (1946).

Dual staining for Fos-ir and markers for the catecholamine phenotype and/or glial fibrillary acidic protein (GFAP) was performed by initially preparing free-floating sections through the medulla for immunoperoxidase localization of Fos-ir as outlined above, except that the hydrogen peroxide pretreatment was omitted. Sections were subsequently incubated in a mouse-derived monoclonal antibody against dopamine- $\beta$ hydroxylase (DBH, a marker for adrenergic and noradrenergic neurons) and phenylethanolamine- $N$-methyltransferase (PNMT, a specific marker for adrenergic neurons) or GFAP (an astroglial marker). The anti-DBH serum (Chemicon, Temecula, CA; diluted 1:1000) was raised against rat adrenal DBH. The anti-PNMT serum (diluted at 1:2000), generously provided by Dr. M. C. Bohn (Rochester University), was raised in rabbits against purified rat adrenal PNMT (Bohn et al., 1987). Anti-GFAP (Chemicon, 1:2000) was a mouse-derived monoclonal antibody raised against porcine GFAP. Primary antisera were localized using a mixture of FITC-labeled goat anti-rabbit IgG (1:200; Tago, Burlingame, CA) and rhodamine-labeled goat anti-mouse $\operatorname{IgG}(1: 100$, American Qualex). Comparison with the distinctive cellular and regional labeling patterns known to be exhibited by these markers, and the results of control experiments involving omission of one or both primary antisera, supported the specificity of each antiserum.

\section{In situ hybridization}

CRF mRNA was detected using a ${ }^{35}$ S-labeled antisense cRNA probe transcribed from a $1.2 \mathrm{~kb}$ full-length cDNA (Dr. K. Mayo, Northwestern University). Control sections were hybridized with sense strand runoffs generated from the same cDNA clone and labeled to similar specific activities. Hybridization histochemical localization was performed as described previously (Simmons et al., 1989). Briefly, sections were mounted on gelatin- and poly-L-lysine-coated slides and desiccated under vacuum overnight. Sections were then post-fixed with neutral-buffered $4 \%$ paraformaldehyde for $30 \mathrm{~min}$, digested in $10 \mu \mathrm{g} / \mathrm{ml}$ proteinase $\mathrm{K}$ at $37^{\circ} \mathrm{C}$ for $30 \mathrm{~min}$, acetylated for $10 \mathrm{~min}$, and then dehydrated and vacuum dried overnight. Hybridization of the radioactively labeled antisense cRNA probes $\left(10^{6} \mathrm{cpm} / 100 \mu \mathrm{l}\right.$ per slide, $\left.5-10 \times 10^{8} \mathrm{dpm} / \mu \mathrm{g}\right)$ was performed in $247 \mathrm{~mm} \mathrm{NaCl}, 8.2 \mathrm{~mm}$ Tris- $\mathrm{HCl}, \mathrm{pH} 8.0$ at $25^{\circ} \mathrm{C}, 41 \%$ (v/v) formamide, $0.82 \times$ Denhardt's solution $(1 \times$ Denhardt's solution is $0.002 \%$ BSA, Ficoll 400, and polyvinylpyrrolidone), $8.2 \%$ (w/v) dextran sulfate, $411 \mu \mathrm{g} / \mathrm{ml}$ yeast tRNA, and $8.2 \mathrm{~mm}$ DTT on coverslipped slides at $60^{\circ} \mathrm{C}$ for $16 \mathrm{hr}$. After initial rinses in $4 \times \mathrm{SSC}$, slides were incubated in RNase A $\left(20 \mu \mathrm{g} / \mathrm{ml}, 37^{\circ} \mathrm{C}, 30 \mathrm{~min}\right)$, washed in $0.1 \times \mathrm{SSC}$ and $10 \mathrm{~mm}$ DTT at $75^{\circ} \mathrm{C}$ for $30 \mathrm{~min}$, and finally dehydrated and dried. Slides were exposed to Amersham (Arlington Heights, IL) $\beta$-Max autoradiography film for 1-4 d, defatted in graded ethanols and xylene, and dipped in Kodak (Rochester, NY) NTB-2 nuclear track emulsion. Slides were exposed for $10-14 \mathrm{~d}$ and developed in D-19 developer (Kodak) for $5 \mathrm{~min}$ at $14^{\circ} \mathrm{C}$. Sections were counterstained with thionin, dehydrated, and coverslipped.

Semiquantitative comparisons of relative levels of CRF mRNA involved preparation of brain paste standards containing serial dilutions of ${ }^{35}$ S-uridine triphosphate, which were sectioned in a cryostat at the same thickness as the experimental material, collected on slides, and fixed with paraformaldehyde in the vapor phase at $60^{\circ} \mathrm{C}$. Unfixed sections adjacent 
to these were counted in a liquid scintillation counter. A standard curve was generated by selecting the curve of best fit that related the optical density of the brain paste standards (which were exposed along with the tissue sections to be used for analysis) to the amount of radioactivity per unit area of the standard. Densitometric analysis of autoradiographic images was performed using Macintosh-driven Image software (version 1.55; W. Rasband, National Institutes of Health, Bethesda, MD). The analysis was performed on slides coded to obscure the treatments to which the animals were exposed. The medial parvocellular subdivision of the PVH (Swanson and Kuypers, 1980) was defined from Nissl staining patterns and aligned with corresponding dark-field images of hybridized sections using redirected sampling. Optical density readings, corrected for background, were taken at regularly spaced $(150 \mu \mathrm{m})$ intervals, and average values were determined for three to five sections though these cell groups for each animal. Data were compared using ANOVA with Scheffe's test for individual pairwise comparisons.

\section{Procedures}

In all experiments, surgery was performed under ketamine/xylazine/ acepromazine anesthesia $(25: 5: 1 \mathrm{mg} / \mathrm{kg}$, s.c.). Animals were processed through each of the paradigms described below in cohorts in which at least one member from each group in the design was represented. Sections were saved in cryoprotectant at $-20^{\circ} \mathrm{C}$ until final group sizes were achieved, allowing tissue from animals in a given experiment to be processed in tandem, using a single batch or radiolabeled probe, or a minimum number of separate incubations and reactions for immunohistochemistry.

Abdominal vagotomy. Rats were anesthetized and submitted to complete subdiaphragmatic vagotomy (Vag-X) or sham operations. Vagotomy was performed as described (Sawchenko and Gold, 1981) and involved laparotomy, followed by independent identification and sectioning of the major branches (anterior and posterior gastric, hepatic, coeliac, and accessory coeliac) and stripping of the esophagus of both trunks to as near the level of the diaphragm as possible. Sham operations were performed similarly, and the vagal branches were isolated but not severed. At the time of surgery, both Vag-X and controls received a ring of six to eight $100 \mathrm{nl}$ injections of the retrogradely transported fluorochrome true blue into the stomach wall just distal to the level of the gastroesophageal junction, to provide an independent index of the effectiveness of vagotomy. Postoperatively rats were offered wet and palatable foods (in addition to lab chow) until body weight stabilized, typically 7-14 d after surgery. Animals were then reinstated on lab chow until rates of weight gain stabilized and implanted with jugular cannulae, and $2 \mathrm{~d}$ later approximately half of each group received intravenous injections of 1.87 $\mu \mathrm{g} / \mathrm{kg}$ IL $-1 \beta$ or vehicle. After $3 \mathrm{hr}$, they were anesthetized with chloral hydrate and perfused, and their brains were prepared for histology.

Area postrema lesions. A similar two-factor design was used, with separate groups of animals receiving either lesions of the area postrema (AP-X) or sham operations and injections of IL- $1 \beta$ or vehicle. Animals were anesthetized and mounted in a stereotaxic device, and the cisternum magnum was exposed after reflection of the atlanto-occipital membrane. Area postrema lesions were performed under visual (microscopic) guidance by aspiration, using a Pasteur pipette drawn to outer and inner diameters of about 0.5 and $0.15 \mathrm{~mm}$, respectively, connected to a vacuum pump drawing 10-12 psi. Sham operations were similar to the point of aspiration. After 2 weeks' recovery, animals were then treated and challenged with IL-1 as described above.

Pretreatment with indomethacin. Rats were implanted with jugular catheters, and $2 \mathrm{~d}$ later, $2 \mathrm{hr}$ after connecting their intravenous lines, they were injected intravenously with indomethacin at $0.25,0.5$, or $1.0 \mathrm{mg} / \mathrm{kg}$, in $0.04 \mathrm{M}$ PBS with $10 \%$ ethanol and $0.1 \%$ ascorbic acid, $\mathrm{pH} 6$, or with vehicle, followed $15 \mathrm{~min}$ later by $1.87 \mu \mathrm{g} / \mathrm{kg}$ IL- $1 \beta$ or vehicle. Three hours after IL-1 infusion they were anesthetized and perfused for histology as above.

Intramedullary PGE2 injection. Rats were anesthetized and stereotaxically implanted with guide cannulae aimed to terminate $1.0 \mathrm{~mm}$ dorsal to the $\mathrm{C} 1$ adrenergic cell group in the rostral VLM at the level of the rostral pole of the lateral reticular nucleus. Cannulae (Plastics One) were affixed to the skull with dental acrylic adhering to jeweler's screws partially driven into the parietal and interparietal bones and were sealed with stylets cut to terminate flush with the tip. Seven to $10 \mathrm{~d}$ later, the stylets were removed and replaced with 30 ga injectors that extended $1.0 \mathrm{~mm}$ beyond the tip of the guide, through which they received local injections of 1, 10, 100, or $1000 \mathrm{ng}$ of PGE2 (Cayman Chemical) in $200 \mathrm{nl}$ of sterile, pyrogen-free saline with 5\% DMSO, or vehicle alone, over 3 min using a pressure ejection device (WPI). Two hours later, the time point at which maximal Fos-ir induction was detected in preliminary experiments, rats were anesthetized and perfused for histology.

\section{Imaging}

All images were captured on Ilford XP-2 negative film, imported into Adobe Photoshop (version 3.0) using a Kodak RS-3570 film scanner, cropped, adjusted to balance brightness and contrast, exported to Canvas (version 3.54) for assembly, and rendered at 300 dots per inch using a Kodak PS-8600 dye sublimation printer.

\section{RESULTS}

\section{Abdominal vagotomy}

There exists substantial literature indicating that the mitigating effects of subdiaphragmatic vagotomy on endotoxin-induced IEG expression in cell groups of interest here, and/or on HPA secretory activity, are most profound when the cytokine is administered intraperitoneally (e.g., Wan et al., 1994; Gaykema et al., 1995). Although compatible findings have been reported in IL-1 challenge paradigms using HPA hormonal output as an end point (Katsuura et al., 1988; Kapcala et al., 1996), analyses at a cellular level have not yet been undertaken using the IL-1 model.

Fos-ir expression in control (sham Vag-X, saline-injected) rats was generally low to nonexistent (Fig. 1). Labeled cells in the NTS and VLM were scattered widely and not observed consistently from section to section. A slightly higher level of basal expression was observed in the PVH in some cases, concentrated in the autonomic-related dorsal, ventral-medial and lateral parts of the parvocellular division. Adjoining aspects of the zona incerta and anterior hypothalamic area displayed more consistent, although still low, levels of nuclear Fos-ir. Injection of IL-1 $\beta$ (1.87 $\mu \mathrm{g} / \mathrm{kg}$, i.v.) provoked robust and reliable Fos induction in each of the regions of interest (Fig. 1), the strength and distribution of which were fully compatible with that described previously using identical parameters (Ericsson et al., 1994). In the dorsal vagal complex, activated neurons were heavily concentrated in the caudal two-thirds of the medial subnucleus of the NTS, with secondary accumulations in the dorsal and commissural parts. Only widely scattered Fos-ir neurons were detected in the area postrema. IL-1-responsive neurons in the VLM were heavily concentrated in the rostral, $\mathrm{C} 1$, region, extending through the C1-A1 transition area at the level of the area postrema and tapered sharply in the A1 region, caudal to the level of the apex of the calamus scriptorus. In the PVH, Fos-ir neurons were preferentially concentrated in the CRF-rich dorsal aspect of the medial parvocellular part of the nucleus. Fos expression in the autonomic-related dorsal, ventral-medial, and lateral parvocellular parts was also reliably elevated over control levels. In the magnocellular division, Fos-ir was low to moderate and overwhelmingly concentrated in regions that preferentially express oxytocin. These included subsets of the anterior, medial, and anteromedial aspects of the posterior magnocellular part of the $\mathrm{PVH}$, as well as the anterior and dorsal portions of the supraoptic nucleus. Counts of the number of Fos-ir neurons in the vagally intact, IL-1-injected group revealed means \pm SEM $(n=5)$ of $716 \pm 73$ labeled nuclei in the NTS, $770 \pm 108$ in the VLM, and $1126 \pm 148$ in the medial parvocellular part of the PVH.

Sham Vag-X animals displayed extensive retrograde labeling from tracer injections in the forestomach throughout the rostrocaudal extent of the dorsal motor nucleus of the vagus, bilaterally (Fig. 2), and of isolated clusters of neurons in the rostral part of the principal column of ambiguual complex (data not shown). No retrograde labeling was observed in any aspect of the medulla of 

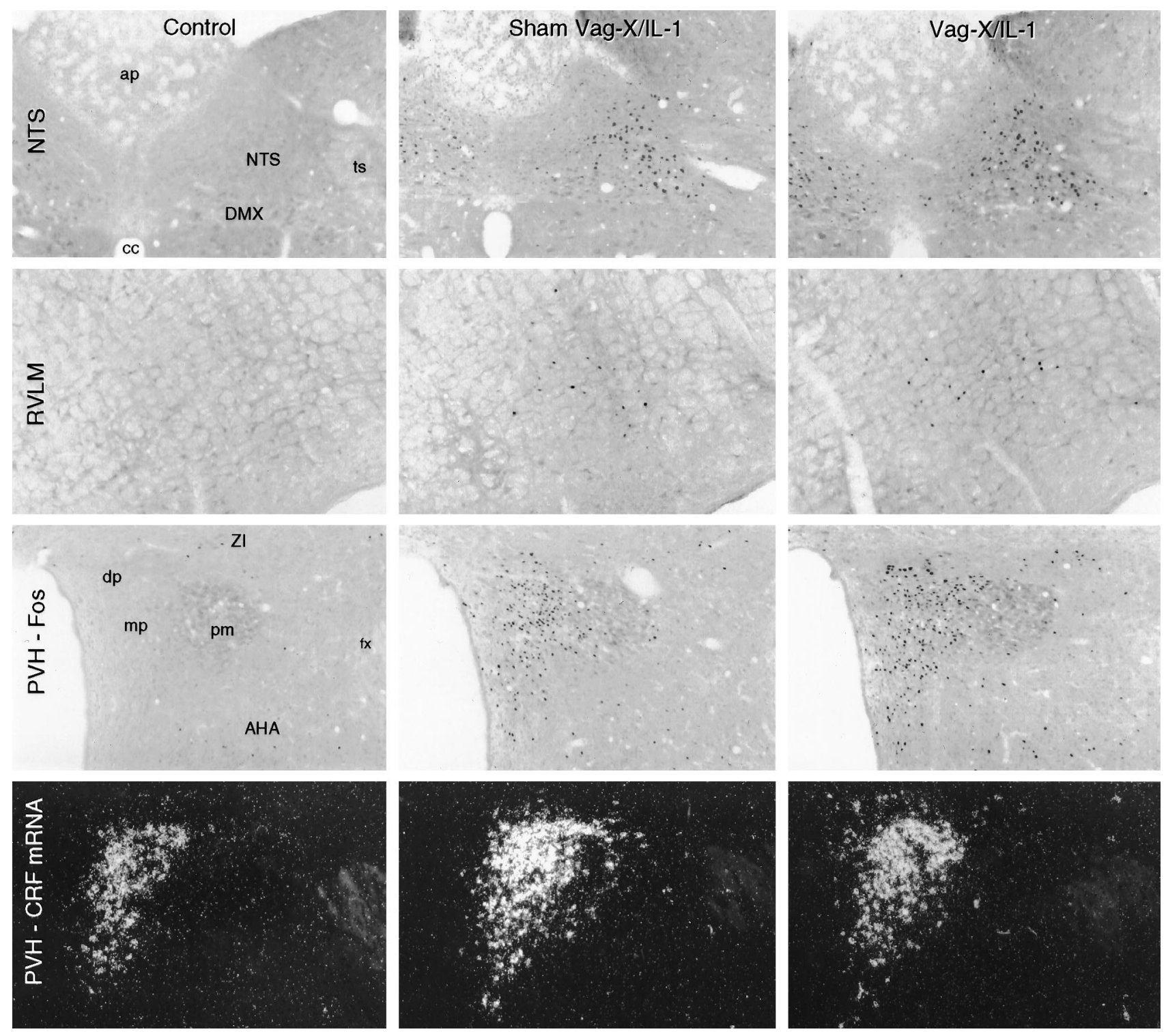

Figure 1. Abdominal vagotomy does not interfere with intravenous IL-1-induced responses in medulla or hypothalamus. Bright-field photomicrographs show Fos-ir expression at comparable levels of the NTS, rostral ventrolateral medulla (RVLM), and PVH, and dark-field photomicrographs show CRF mRNA signal in the PVH in a representative sham-vagotomized rat killed $3 \mathrm{hr}$ after intravenous saline injection (Control; left), a sham-vagotomized rat killed at $3 \mathrm{hr}$ after intravenous injection of $1.87 \mu \mathrm{g} / \mathrm{kg}$ IL-1 $\beta$ (Sham Vag-X/IL-1; middle), and an animal that sustained complete abdominal vagotomy before a similar IL-1 challenge (Vag-X/IL-1; right). In vagally intact animals, IL-1 provoked robust induction of nuclear Fos-ir in each region, along with increased relative levels of CRF mRNA. None of these responses to intravenous IL-1 was altered perceptibly in vagotomized rats. Magnification, $50 \times$. $A H A$, Anterior hypothalamic area; $a p$, area postrema; $D M X$, dorsal motor nucleus of the vagus; $d p$, dorsal parvocellular part (PVH); $f x$, fornix; $t s$, solitary tract; $m p$, medial parvocellular part (PVH); $p m$, posterior magnocellular part $(\mathrm{PVH}), Z I$, zona incerta.

Vag-X animals, providing a measure of support for the effectiveness of vagal denervations.

Among saline-injected rats, Vag-X exerted no discernible influence on the presumably basal pattern of Fos-ir expression in hypothalamus or medulla seen in sham-operated controls, and no measured effect on the very low numbers of immunoreactive cells counted in the NTS, VLM, or PVH $(p>0.10)$. Similarly, Vag-X failed to alter IL-1-induced Fos expression significantly in any of these regions of interest, with counts in the hypophysiotropic zone of the PVH averaging $105 \pm 14 \%$ of sham Vag-X, IL-1injected values. In the medulla, we noted a tendency for IL-1stimulated Fos-ir to be reduced in the subpostrema region of Vag-X relative to sham-operated animals, but yet the combined total number of responsive neurons counted in the NTS and
VLM did not differ significantly, with stimulated and Vag-X values averaging $91 \pm 13 \%$ of counts obtained from their shamoperated counterparts $(p>0.10)$.

Densitometric assessments of relative levels of CRF mRNA, performed to provide an independent and functionally relevant assessment of Vag-X effects on the effector population of principal interest in the PVH, revealed no significant effects of vagal surgery on basal or IL-1 stimulated measures. Relative to shamoperated, saline-injected controls, IL-1 provoked reliable $67.3 \pm$ $10.4 \%$ and $53.6 \pm 8.3 \%$ increases in CRF mRNA in shamoperated and Vag-X animals, respectively (both $p<0.01$ ). These increments did not differ significantly from one another $(p>$ $0.10)$. Overall, we failed to find support for a significant dependence on abdominal vagal mechanisms of stimulatory effects of 


\section{Abdominal Vagotomy}
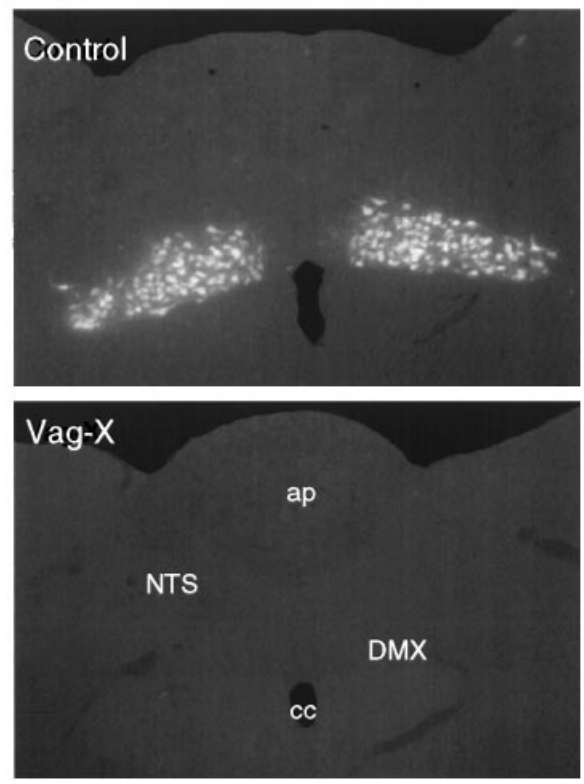

\section{Area Postrema Lesions}
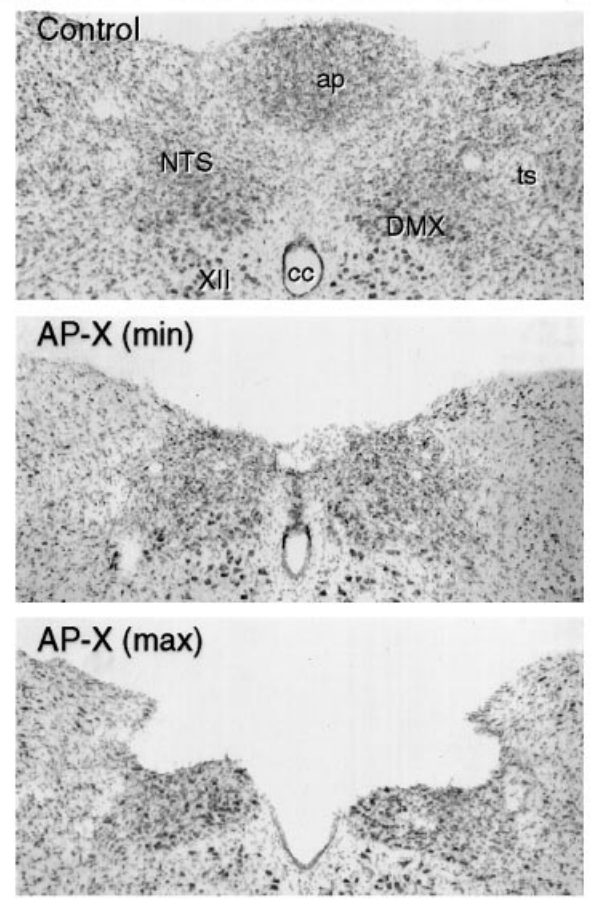
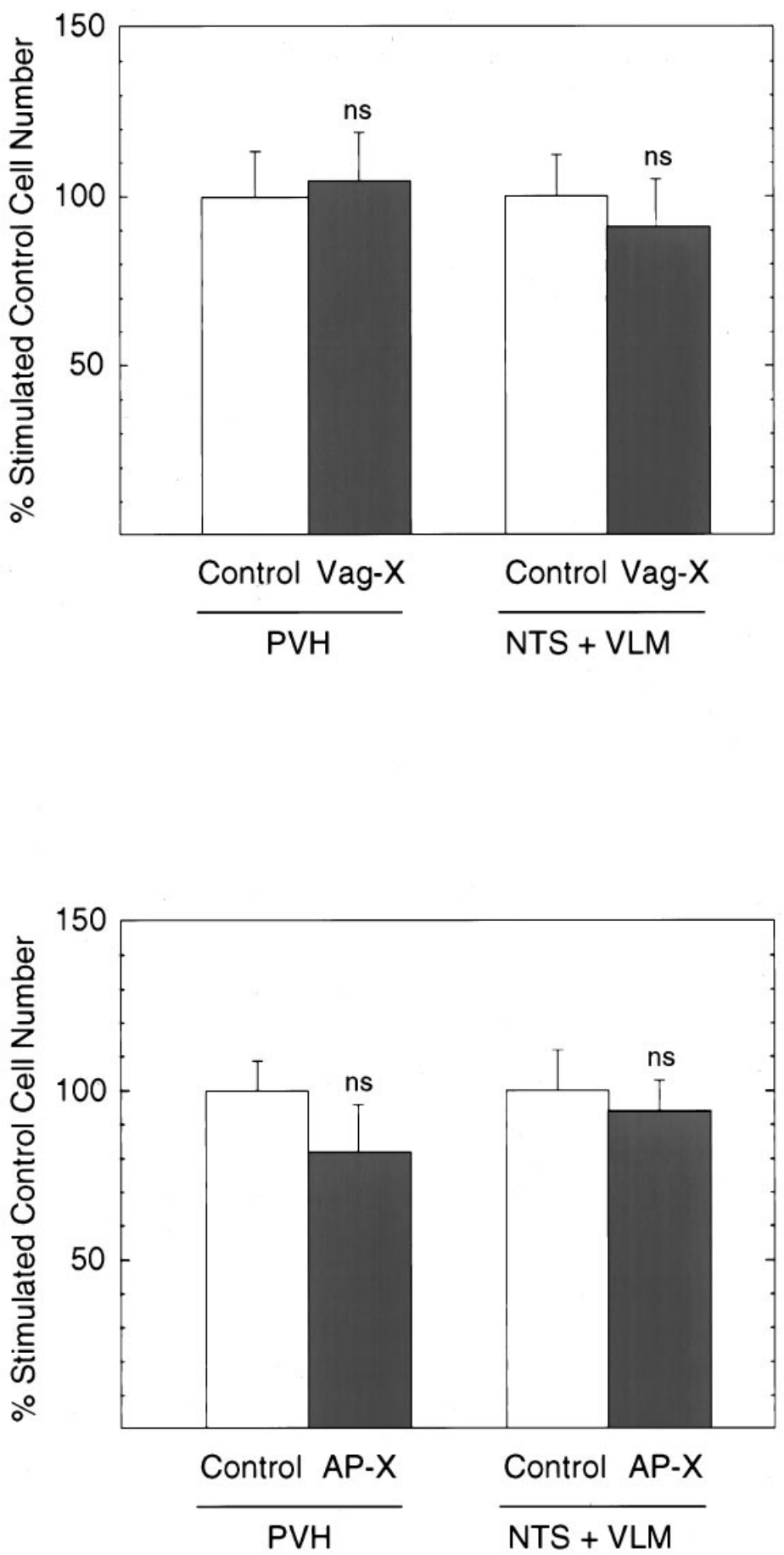

Figure 2. Neither abdominal vagotomy nor lesion of the area postrema modifies Fos expression in the medulla or hypothalamus induced by intravenous IL-1. Bar graphs show the effects of subdiaphragmatic vagotomy $(V a g-X$; top $)$ or aspiration lesions of the area postrema $(A P$ - $X$; bottom $)$ on the number of cells displaying IL-1-induced Fos-ir in the VLM and NTS (left) and PVH (right). Data are expressed as mean \pm SEM percentage of counts obtained in sham Vag-X or sham AP-X animals treated with intravenous IL-1. $n=5$ or 6 per group. $n s$, Nonsignificant versus stimulated control values $(p>0.10)$. Photomicrographs to the left of each graph provide documentation of the effectiveness or extent of the ablations. Top, Fluorescence photomicrographs showing the robust retrograde labeling displayed by vagally intact rats of cells in the dorsal motor nucleus of the vagus as a consequence of fluorescent tracer injections placed in the wall of the stomach at the time of surgery and the complete lack of such labeling in a Vag-X animal. Magnification, 50 $\times$. Bottom, Bright-field photomicrographs of Nissl-stained sections through the level of the maximal development of the area postrema, showing the appearance of the region in a sham-operated control and in rats that incurred minimal ( $\min$ ) or maximal ( $\max$ ) damage to underlying aspects of the NTS. ap, Area postrema; $c c$, central canal; $D M X$, dorsal motor nucleus of the vagus; $t s$, solitary tract; $X I I$, hypoglossal nucleus. Magnification, $35 \times$. 
increased circulating levels of IL-1 at the level of either the medulla or the hypothalamus under the conditions in force in this experiment.

\section{Lesions of the area postrema and medial NTS}

The area postrema, the circumventricular component of the dorsal vagal complex, was identified previously as the only site apart from perivascular cells that exhibited both constitutive IL-1R1and IL-1-induced IEG expression, under the dosage and treatment conditions used here (Ericsson et al., 1995a). In view of the fact that the major projections issued by the area postrema permit its influences to be exerted directly on the NTS, and at least indirectly on the VLM (Cunningham et al., 1994), it is a viable candidate for participating in IL-1-mediated effects on HPA control systems.

Aspiration lesions were effective in removing all recognizable remnants of the area postrema in six IL-1-injected rats and five animals challenged subsequently with vehicle. The lesioned area also consistently included portions of the underlying, and relatively cell-sparse, subpostrema region (Fig. 2). Three animals (two of which were subsequently injected with IL-1 and one with saline) sustained more extensive damage, which included substantial portions of the dorsal and medial subnuclei of the NTS, extending in the most extreme case nearly to the medial margin of the solitary tract.

In sham-lesioned rats, both IL-1-stimulated and nonstimulated patterns of Fos-ir expression in hypothalamus, medulla, and elsewhere were in all respects similar to those described above, although the strength of Fos induction in this experiment was somewhat less than that seen in the previous experiment. In five nonlesioned, IL-1-injected rats, cell counts provided estimates of $615 \pm 82$ labeled nuclei in the NTS, $543 \pm 51$ in the VLM, and $844 \pm 68$ in the medial parvocellular part of the PVH. As was the case with vagotomy, lesions of the area postrema failed to reduce IL-1-stimulated Fos-ir expression significantly in either the PVH or in the NTS and VLM, where counts in AP-X, IL-1-treated rats averaged $82 \pm 13$ and $94 \pm 9 \%$ of stimulated control values $(p>$ 0.10) (Fig. 2). Similarly, relative levels of CRF mRNA in these two groups were both reliably elevated $(56 \pm 13 \%, p<0.01$; and $42 \pm 11 \%, p<0.05$, respectively) over sham-lesioned, vehicleinjected control values, and did not differ significantly from one another $(p>0.10)$.

It is of interest to note that even the two lesioned, IL-1-treated animals that sustained more extensive damage to the medial NTS displayed Fos induction with its normal topography in aspects of the NTS that were spared by the lesion, and that counts of the number of labeled cells in the VLM (593 and 641) and PVH (687 and 811 ) from these two animals fell comfortably within the range of those derived from rats sustaining more discrete damage.

\section{Prostaglandin synthesis inhibition}

Prostaglandin-dependent mechanisms have been implicated in the IL-1 stimulation of the secretory activity of the HPA axis (Watanabe et al., 1990; Rivier and Rivest, 1993; Tilders et al., 1994; Watanobe et al., 1995). If prostaglandins and medullary catecholamine-containing neurons are both involved in this activation, then both aminergic neurons and their hypothalamic targets would be expected to respond similarly to graded levels of prostaglandin synthesis blockade. This notion was tested by pretreating rats with systemic injections of the cyclooxygenase inhibitor indomethacin $15 \mathrm{~min}$ before an intravenous IL challenge.

Rats pretreated with the vehicle used for indomethacin admin- istration and subsequently challenged with IL-1 displayed very prominent activation of Fos expression in the NTS, VLM, and PVH, fully compatible with that described above (Figs. 3, 4). This was accompanied by a reliable, $59 \pm 7 \%$, increase in relative levels of CRF transcripts in the medial parvocellular part of the PVH ( $p<0.01$ vs vehicle/vehicle-treated controls).

Although intravenous treatment with the higher dose of indomethacin $(1.0 \mathrm{mg} / \mathrm{kg})$ alone (i.e., in the absence of subsequent IL-1 treatment) tended to reduce the low levels of Fos-ir expression in all areas analyzed relative to controls, none of these differences was reliable (all $p>0.10$ ). Particularly significant is the fact that relative levels of CRF mRNA, which is constitutively expressed, were also not significantly altered as a consequence of higher-dose indomethacin treatment, averaging $85 \pm 4 \%$ of values derived from vehicle/vehicle-treated rats.

Among IL-1-injected animals, indomethacin pretreatment produced clear dose-related decrements in the number of Fos-ir neurons counted in both regions of the medulla, as well as in the $\mathrm{PVH}$, that were statistically reliable at the lowest $(0.25 \mathrm{mg} / \mathrm{kg})$ dose and that were not significantly elevated above control values at the higher of the three doses used $(1.0 \mathrm{mg} / \mathrm{kg}$; see Figs. 3,4$)$. Although only the medial parvocellular part of the PVH was analyzed quantitatively, IL-1-stimulated Fos induction in the magnocellular and autonomic-related subdivision of the nucleus appeared clearly to be similarly responsive to systemic treatment with the cyclooxygenase inhibitor. IL-1-stimulated increases in relative levels of CRF mRNA in the PVH responded in a lessgraded manner to indomethacin pretreatment, being nonsignificantly affected, relative to the vehicle/IL-1-treated group, at the lower dose, and not differing reliably from vehicle/vehicle-treated rats at both higher ones. Overall, these results provide strong support for an involvement of a prostaglandin-dependent mechanism in IL-1-stimulated cellular responses at the levels of the medulla and hypothalamus. The comparable sensitivities exhibited by cell groups at both levels to indomethacin treatment is consistent with the view that they constitute a unified system that lies distal to the prostaglandin-dependent step.

\section{Local prostaglandin microinjection}

Recent findings localizing a prostaglandin E2 receptor subtype (EP3) in the region of medullary aminergic neurons (Ericsson et al., 1995b), but not in hypothalamus, raises the possibility that prostanoids released by the perivascular cells as a consequence of IL-1 stimulation might act locally to stimulate nearby aminergic neurons. Such a view would predict that microinjections of PGE2 into the region of the $\mathrm{C} 1$ catecholamine cell group, the major seat of IL-1-responsive medullary aminergic cells that project to the PVH (Ericsson et al., 1994), should provoke IEG responses in C1 cells and at least partially recapitulate the effects of intravenous IL-1 injection at the level of the PVH.

Examples of injection cannula placements above the $\mathrm{C} 1$ region of the rostral VLM are shown in Figure 5. Immunoperoxidase localization of Fos revealed a mixture of both large (presumably neuronal) and smaller (presumably astrocytic) labeled nuclei closely associated with the cannula track and extending longitudinally in a $300-450 \mu \mathrm{m}$ radius from the center of the injection site. Material stained for combined immunofluorescence localization of Fos-ir and GFAP-ir revealed numerous astrocytes intensely labeled for GFAP within and around the region invaded by the tip of the injector; this was surrounded by a band of larger Fos-ir nuclei, beyond which GFAP-ir tapered sharply to levels comparable to those observed at a corresponding locus on the 

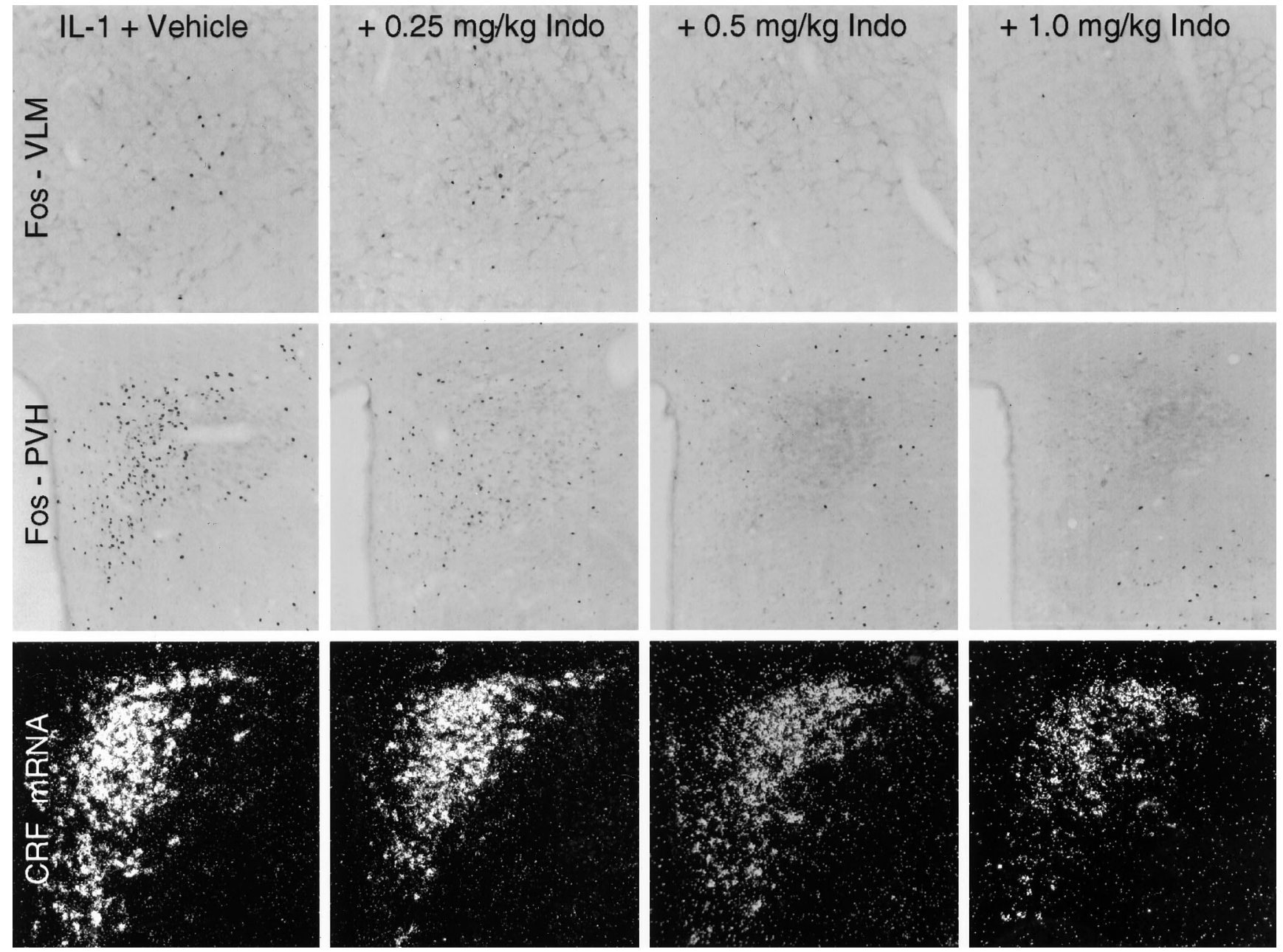

Figure 3. Effects of graded levels of prostaglandin synthesis blockade on IL-1-stimulated Fos-ir and CRF mRNA expression. Bright-field photomicrographs show sections through similar levels of the PVH (top) and rostral ventrolateral medulla (bottom) stained for Fos-ir, and dark-field photomicrographs show PVH sections hybridized with probes for CRF mRNA (middle) from animals pretreated intravenously with either vehicle of varying doses of indomethacin (Indo) $15 \mathrm{~min}$ before an intravenous challenge with $1.87 \mu \mathrm{g} / \mathrm{kg}$ IL- $1 \beta$. Indomethacin pretreatment produces a dose-related decrease in the expression of Fos-ir and CRF mRNA in the PVH and of Fos-ir in the region of the C1 catecholamine cell group. The patterns and strength of expression of both markers in the PVH and of Fos-ir in the VLM at the higher indomethacin doses are not distinguishable from those seen in rats injected with vehicle in lieu of IL-1. Note that Fos-ir expression in the regions immediately adjoining the PVH is ostensibly unaffected by any dosage of indomethacin. Magnification, $60 \times$.

contralateral side (Fig. 5). This basic pattern of Fos and GFAP labeling near the tip of the injector did not vary systematically as a function of PGE2 dose or between PGE2- and vehicle-treated animals, and we interpret it as being indicative of nonspecific consequences of the injections. Beyond this, however, rats injected with $100 \mathrm{ng}$ of PGE2 and, to a lesser extent, those receiving $10 \mathrm{ng}$ displayed remarkably discrete Fos-ir expression concentrated in the $\mathrm{C} 1$ region of the rostral VLM (Fig. 6). This extended well beyond the zone at which reactive astrocytes were observed and throughout most of the rostrocaudal extent of the $\mathrm{C} 1$ cell group in animals treated with $100 \mathrm{ng}$ doses. No other recognized cell group or field of the ventral medulla displayed consistent PGE2-stimulated Fos expression. Co-staining of series of sections through the medulla for DBH-ir and PNMT-ir revealed that a substantial majority of all Fos-ir cells beyond the zone of reactive astrocytosis surrounding the injection site were adrenergic. Interestingly, higher doses of PGE2 also provoked Fos-ir expression in the medial NTS, albeit with lesser consistency than in the VLM; it is not clear whether this may occur as a secondary consequence of activation more ventrally or directly as a result of injectate diffusing along the guide cannula tracks, which invariably impinged on the NTS. A lesser, although still substantial, fraction of Fos-ir neurons in the NTS displayed PNMT-ir and/or DBH-ir.

At the level of the PVH, intramedullary injections of $100 \mathrm{ng}$ of PGE2 induced prominent Fos induction, the distribution of which closely mirrored that seen in response to intravenous IL-1 injections (Figs. 6, 7). Thus, the response was most pronounced in the CRF-rich dorsal-medial parvocellular subdivision, with only slightly less prominent foci in the autonomic-related dorsal, ventral-medial, and lateral parvocellular parts and in all parts of the magnocellular division. Fos-ir was heavily concentrated in aspects of the magnocellular neurosecretory system in which oxytocin-expressing neurons are concentrated, including the anterior, medial, and discrete aspects of the posterior magnocellular parts of the PVH (including the ring-like array seen at the level illustrated in Fig. 6), and with a crisp anterior and dorsal emphasis in the supraoptic nucleus. Aspects of this pattern, principally activation in the parvocellular division of the PVH, were weakly 

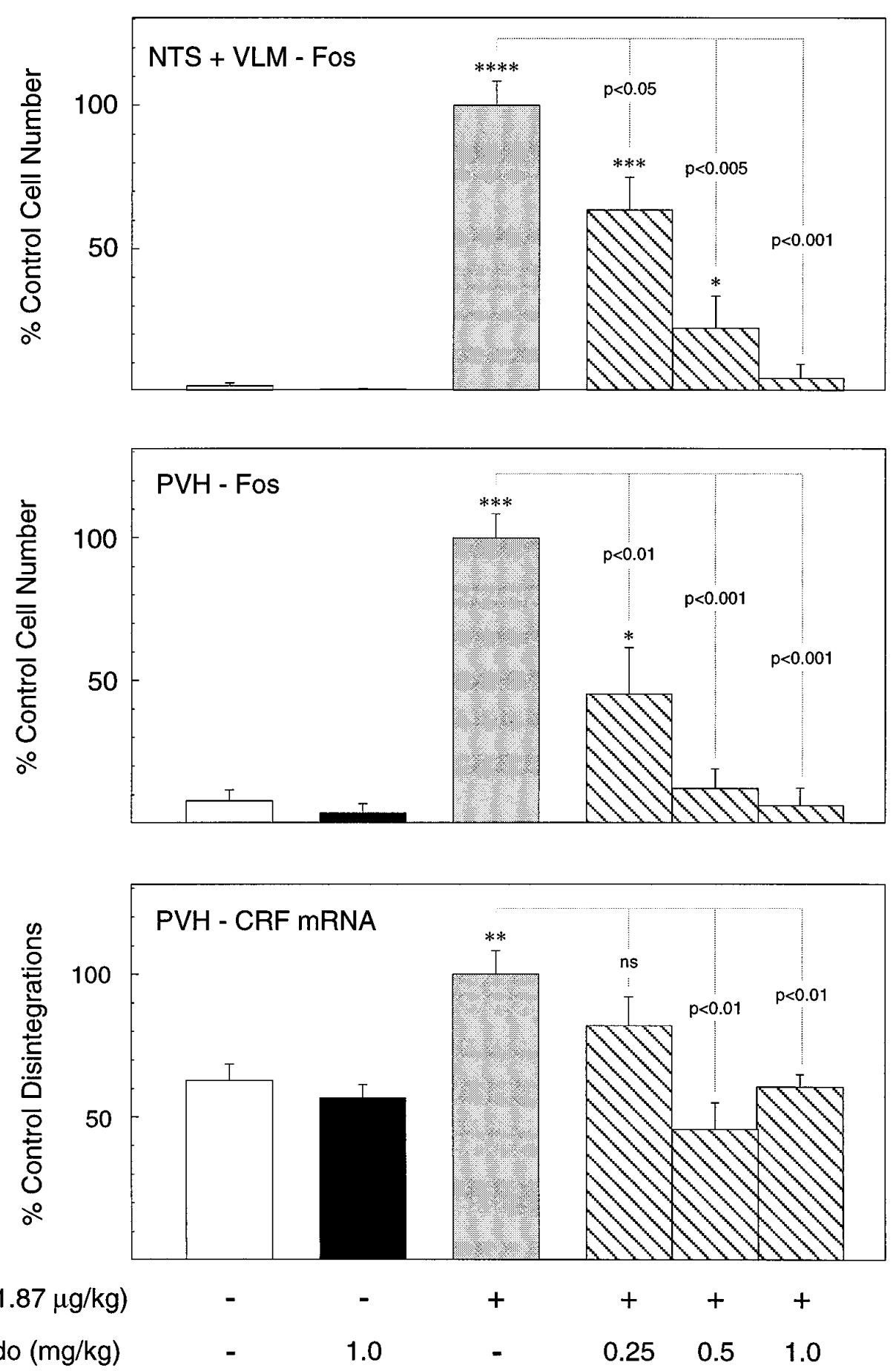

Figure 4. Dose-related inhibition by systemic indomethacin of IL-1 effects in hypothalamus and medulla. Mean \pm SEM number of Fos-ir neurons in the NTS and VLM combined (top), the PVH (middle), and relative levels of CRF mRNA (bottom) of rats as a function of treatment condition. Data are expressed as a percentage of values counts derived from vehicle-pretreated rats that were challenged with IL-1. $n=4-7$ per group. The key at the bottom indicates the status of the group: -, vehicle-injected; + , intravenous injection of $1.87 \mu \mathrm{g} / \mathrm{kg} \mathrm{IL}-1 \beta ; 0.25,0.5$, and 1.0 , doses of indomethacin administered 15 min before treatment with IL-1 or its vehicle. IL-1 provokes a robust induction of Fos expression in both hypothalamus and medulla that are antagonized in parallel, dose-related manners by indomethacin. Cytokine-mediated upregulation of CRF mRNA is eliminated at both higher doses of indomethacin but is not significantly affect by the lowest one. ${ }^{*} p<0.05$; ${ }^{* *} p<0.01 ;{ }^{* * *} p<0.005 ; * * * p<0.001$ versus control (saline/saline-treated) rats; $n s$, nonsignificant. Additional comparisons are indicated by $p$ values.

apparent in most animals receiving $10 \mathrm{ng}$ doses of PGE2. Injections of $1 \mathrm{ng}$ uniformly failed to elicit Fos expression in any aspect of the hypothalamus that was distinguishable from the very low levels seen in vehicle-injected controls.
Quantitative analyses revealed that although intramedullary injection of $1 \mathrm{ng}$ of PGE2 failed to elicit a significant increase in the number of Fos-ir neurons estimated in the medial parvocellular part of the PVH, relative to vehicle-treated controls (51 \pm 

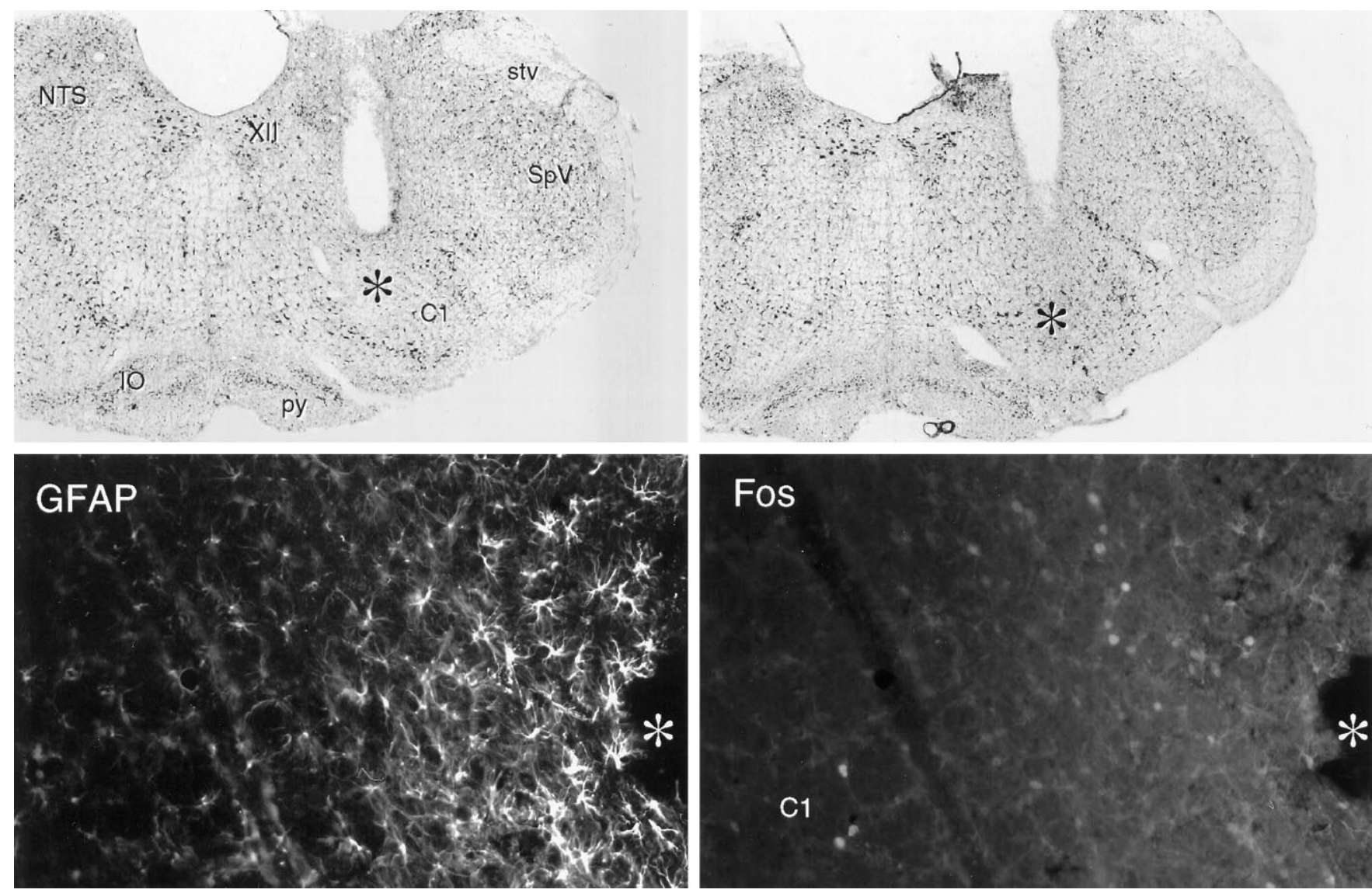

Figure 5. Cannula placements and local effects of intramedullary microinjection of PGE2. Top, Bright-field photomicrographs of Nissl-stained sections showing cannula placements in the rostral ventrolateral medulla. Magnification, 15×. Bottom, Fluorescence photomicrographs of a single field near a cannula tip in the ventrolateral medulla stained concurrently for GFAP-ir and Fos-ir. Surrounding the area of tissue damage (*) is a region of intense GFAP labeling of reactive astrocytes. At the margin of this zone lies a band of Fos-ir neurons, which we take to be nonspecifically induced as a consequence of microinjection. Beyond this, GFAP labeling tapers precipitously to levels indistinguishable from those seen at a comparable locus on the contralateral side, and Fos-ir is seen in the $\mathrm{C} 1$ region of the rostral ventrolateral medulla in rats injected with suprathreshold doses of PGE2. XII, Hypoglossal nucleus; stv, spinal trigeminal tract; $S p V$, spinal trigeminal nucleus; $p y$, pyramidal tract; $I O$, inferior olivary complex. Magnification, $150 \times$.

11 vs $39 \pm 9 ; n=4$ and 5 , respectively; $p>0.10), 10 \mathrm{ng}$ doses provoked a weak, but reliable, effect $(87 \pm 16 ; n=6 ; p<0.05)$, and $100 \mathrm{ng}$ stimulated a strong activation $(1211 \pm 138 ; n=4 ; p<$ $0.001)$ exceeding that commonly observed in the experiments described above in response to intravenous IL-1 treatment. Comparisons of relative levels of CRF mRNA in animals receiving the higher $(100 \mathrm{ng})$ dose with controls revealed a marked, 1.9-fold, increase $(p<0.001)$.

\section{DISCUSSION}

Neither abdominal vagotomy nor lesions of the area postrema reliably altered Fos-ir induced in the NTS, VLM, and PVH by intravenous administration of a moderately suprathreshold dose of IL-1 $\beta$. Cytokine-stimulated increases in relative levels of CRF mRNA in the hypophysiotropic zone of the PVH were also unaffected by either ablation. By contrast, systemic administration of the cyclooxygenase inhibitor indomethacin resulted in parallel dose-related attenuations of IL-1 effects in hypothalamus and medulla. Microinjections of PGE2 in the region of the $\mathrm{C} 1$ catecholamine cell group, the principal seat of IL-1-sensitive neurons that project to the $\mathrm{PVH}$, provoked surprisingly discrete patterns of cellular activation in the hypothalamus and medulla that closely mimicked those seen in response to intravenous IL-1. Coupled with previous work on this topic, we take these data as suggesting a mechanism for stimulation of CRF-expressing parvocellular neurosecretory neurons by circulating IL-1 that includes (1) IL-1 binding of its type 1 receptor on cells lining the medullary vasculature with consequent local release of prostanoids, most likely PGE2, into the extracellular space; (2) PGE2 interacting with cognate receptors expressed on or near medullary aminergic neurons, resulting in activation of this population; and (3) consequent synaptic excitation of hypophysiotropic CRF neurons, by way of well documented direct axonal projections (see Fig. 8).

\section{Vagotomy}

Medullary catecholamine-containing neurons are acknowledged as playing pivotal roles in dispersing visceral sensory information to relevant effectors, prominently including ones in the endocrine hypothalamus. Support for a role of vagal sensory mechanisms in mediating central effects of immune challenges may be found in the observations that glomus cells of abdominal vagal paraganglia bind biotinylated IL-1 receptor antagonist (Goehler et al., 1994), suggesting the existence vagal IL-1 receptors, and that administration of IL-1 into the hepatic portal vein results in increased electrical activity of the hepatic branch of the vagus (Nijima, 1992). Our failure to observe reliable effects of subdiaphragmatic vagotomy on cellular responses in the medulla and hypothalamus 

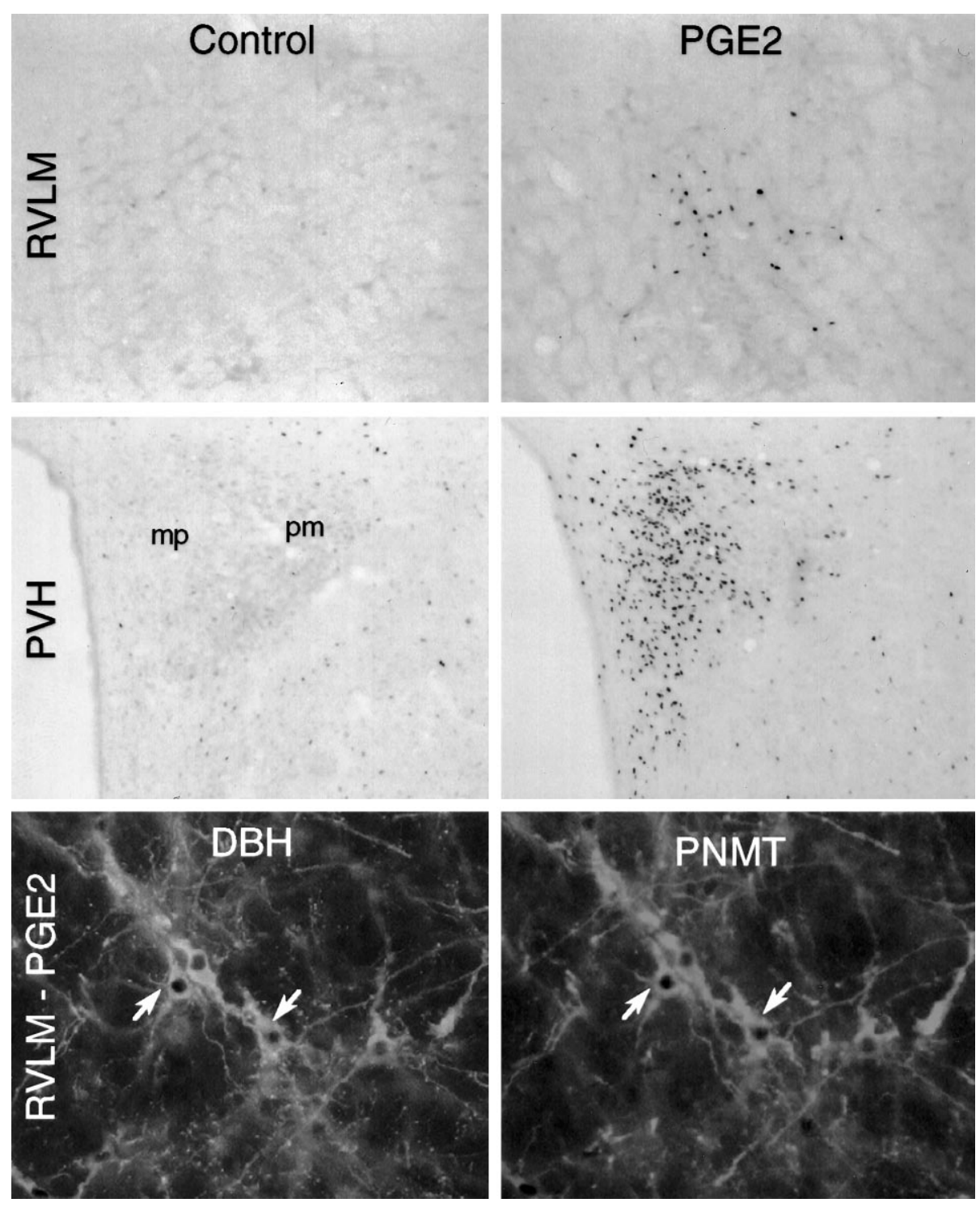

to an intravenous IL-1 challenge is in line with the consensus of previous work on this topic, which supports a much more important role for the abdominal vagi in mediating central responses to cytokines or endotoxin administered intraperitoneally than it does to similar doses of the same agents given intravenously (Katsuura et al., 1988; Wan et al., 1994; Gaykema et al., 1995; Kapcala et al., 1996). It is important to point out, however, that because rats do not survive cervical vagotomy, the possible involvement of thoracic receptor mechanisms that may be innervated by sensory elements of the cervical vagus and/or glossopharyngeal nerves remains to be considered experimentally.

\section{Area postrema and NTS}

A potential role for the area postrema in IL-1 stimulation of the systems of interest here was suggested by our observation that the area postrema was the only site, apart from perivascular cells, at which we observed both IL-1R1 expression and IL-1-stimulated IEG expression (of NGFI-B, but not Fos), using the same cytokine injection parameters used in the present experiments (Ericsson et al., 1995a). The major projections issued by the area postrema ramify in the aspects of the NTS that harbor catecholamine neurons of the A2 and $\mathrm{C} 2$ cell groups (Cunningham et al.,
Figure 6. Microinjections of PGE2 in the rostral ventrolateral medulla mimic the effects of intravenous IL-1. Top and middle, Bright-field photomicrographs showing immunoperoxidase localization of Fos-ir in the rostral ventrolateral medulla (RVLM; top) and PVH (middle) from animals that received intramedullary injections of $200 \mathrm{nl}$ of vehicle (Control) or $100 \mathrm{ng}$ of PGE2 in the same volume (PGE2). Medullary sections are taken from levels $300 \mu \mathrm{m}$ rostral to center of the injection site. PGE2 but not vehicle injection stimulates Fos induction strongly and discretely in both medulla and hypothalamus. The pattern in hypothalamus, primarily involving cells in the CRF-rich aspects of the medial parvocellular part $(m p)$, and secondarily cells in the dorsal parvocellular part and at the periphery of the posterior magnocellular part $(\mathrm{pm})$, conforms closely to the pattern elicited by intravenous IL-1 injections. Magnification, $75 \times$. Bottom, fluorescence photomicrographs of a single section through the A1- $\mathrm{C} 1$ transition area of the ventrolateral medulla from an animal that received intramedullary injection of $100 \mathrm{ng}$ of PGE2 and processed for concurrent immunoperoxidase demonstration of Fos-ir (dark nuclei) and immunofluorescence demonstration of DBH-ir (left) and PNMT-ir (right). Examples of cells displaying all three markers are indicated (arrows). Magnification, $250 \times$.
1994). Influences of the area postrema on the VLM may be mediated directly, via projections that traverse the regions of the $\mathrm{A} 1$ and $\mathrm{C} 1$ cell groups en route to the parabrachial nucleus or, more likely, indirectly, through NTS-VLM interactions. Despite the fact that it is well positioned to participate in cytokinemediated activation of HPA control systems and may well do so under certain circumstances, the results of our lesion study offered no support for an involvement of the area postrema in mediating IL-1 effects at the level of the medulla or hypothalamus, under the treatment conditions in force in our experiments.

\section{Prostaglandins}

Systemic injection of IL-1 provokes increased levels of PGE2 in the general circulation (Rotondo et al., 1988; Watanobe et al., 1995), and pretreatment of rats with inhibitors of cyclooxygenase, the rate-limiting enzyme in prostaglandin synthesis, blocks or significantly attenuates ACTH secretion to intravenous IL-1 (Watanabe et al., 1990). Such findings have commonly been taken as supporting an intermediary role for circulating PGE2 in conveying cytokine signals to central or peripheral receptors, but recent evidence is at least equally as strong in suggesting that the prostaglandin-dependent mechanism may reside within the brain 


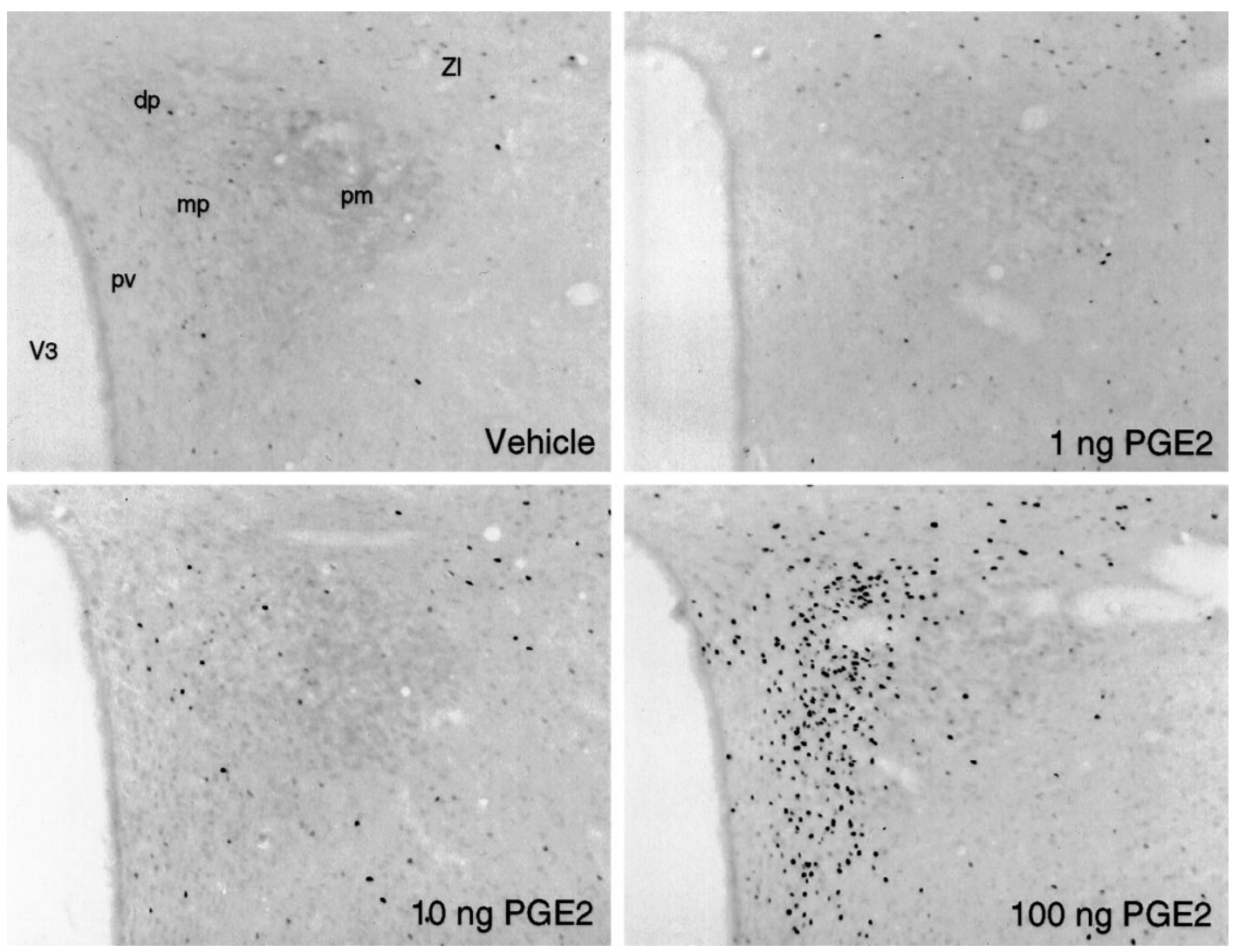

Figure 7. Dose-related Fos-ir expression in the PVH after intramedullary PGE2 injections. Bright-field photomicrographs of section through comparable levels of the PVH show immunoperoxidase localization of Fos-ir seen in response to microinjections of various doses of PGE2 or vehicle. A modest effect is noted at the $10 \mathrm{ng}$ dose, and a much more robust one is noted at $100 \mathrm{ng}$. $d p$, Dorsal parvocellular part; $m p$, medial parvocellular part; $p m$, posterior magnocellular part; $p v$, periventricular part; $Z I$, zona incerta. Magnification, $75 \times$.

parenchyma. Our observation that graded levels of prostaglandin synthesis inhibition provoke comparable dose-related blockades of IL-1-induced cellular activation responses in the NTS, VLM, and $\mathrm{PVH}$ is consistent with the view that the prostanoiddependent step in the IL-1-mediated drive to the central limb of the HPA axis lies distal to the level of medullary aminergic neurons. In addition to expressing IL-1R1 (Cunningham et al., 1992; Yabuuchi et al., 1994; Ericsson et al., 1995a), cells lining aspects of the cerebral vasculature express cyclooxygenaseimmunoreactive material in vivo (Breder et al., 1992), and systemic administration of bacterial endotoxins stimulate release of PGE2-like immunoreactivity from the brain microvasculature (Van Dam et al., 1993). Ligand-binding studies have identified PGE2 receptor-like activity in the rat CNS, with the highest levels observed in the medial preoptic area and in the NTS (Matsumura et al., 1992).

A number of structurally related PGE2 receptors have been identified and designated EP1-4 (Coleman et al., 1989), and cDNAs encoding each have been cloned in rat and/or mouse (Sugimoto et al., 1992; Honda et al., 1993; Takeuchi et al., 1993; Watabe et al., 1993; Nishigaki et al., 1995). All are members of the superfamily of G-protein-coupled receptors characterized by seven transmembrane domains. Northern analyses have identified the EP3 subtype as the predominant form expressed in rodent brain (Sugimoto et al., 1992; Honda et al., 1993; Watabe et al., 1993). We have isolated an EP3 cDNA from rat kidney and have found this transcript to display a restricted central distribution that includes regions of the NTS and VLM in which IL-1- sensitive catecholamine neurons are massed. Expression in hypothalamus is largely limited to the medial preoptic area; specific labeling has not been observed over the PVH (also see Sugimoto et al., 1994; Ericsson et al., 1995b).

These observations provide a basis for understanding the surprisingly discrete local patterns of Fos induction observed in the medulla after PGE2 microinjection. The fact that these injections faithfully recapitulated the effects of intravenous IL-1 administration on the pattern of Fos induction and CRF mRNA expression in the PVH fulfills a prediction that necessarily follows from our model. Evidence supporting alternative mechanisms is available. Intrahypothalamic injections of PGE2 (25 ng) have been shown to stimulate ACTH secretion (Watanabe et al., 1990), and evidence that the PVH expresses the EP1 prostanoid receptor has been provided (Båtshake et al., 1995). In addition, cells in the medial preoptic area identified as projecting to the $\mathrm{PVH}$ have been shown to display lipopolysaccharide (LPS)-induced Fos expression (Elmquist and Saper, 1996), and injections of PGE2 into the preoptic area provoke Fos induction in the PVH with a sensitivity greater than that observed at our placements in the medulla (Scammell et al., 1996). Lacking a systematic and direct comparison, the primacy of these alternative means of accessing HPA control mechanisms cannot currently be assessed. Scammell and colleagues (1996) used smaller volumes to target a discrete cell group, whereas we used larger ones in an effort to involve as much of the more diff use and longitudinally organized $\mathrm{C} 1$ cell group as possible. Our working hypothesis emphasizing the role of medullary afferents, as opposed to more direct effects or 


\section{Markers}
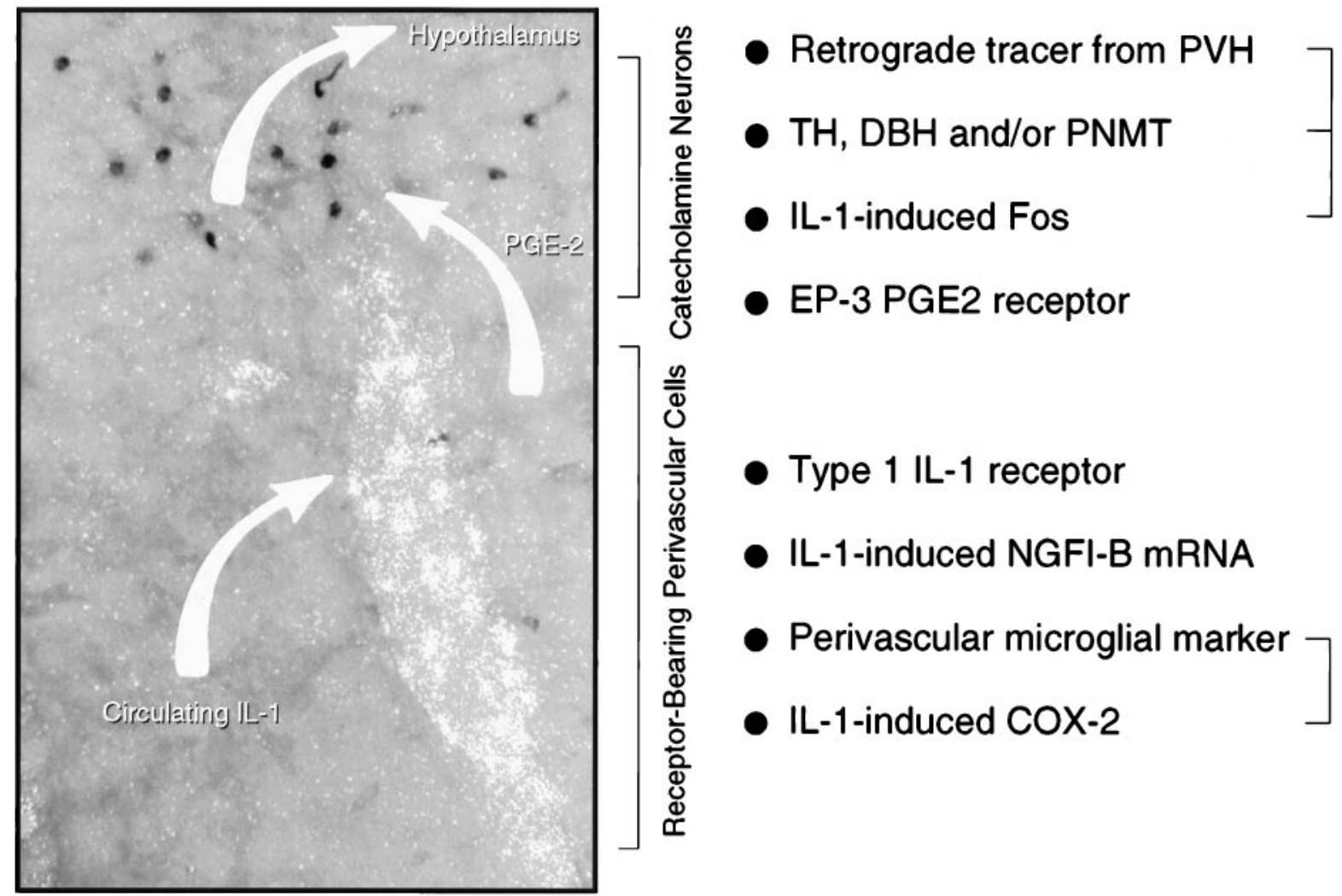

- EP-3 PGE2 receptor

- Type $1 \mathrm{IL}-1$ receptor

- IL-1-induced NGFI-B mRNA

- Perivascular microglial marker

- IL-1-induced COX-2

Figure 8. Possible mechanism for intravenous IL-1-mediated stimulation of central HPA control systems. A polarized epifluorescence illumination image of a section through the rostral ventrolateral medulla shows combined hybridization histochemical localization of perivascular cells displaying IL-1R1 mRNA and immunoperoxidase detection of nuclear Fos-ir in the region of the C1 catecholamine cell group. We suggest that circulating IL-1 binds its cognate receptor on perivascular cells in the region, inducing them to synthesize PGE2, which in turn diff uses through the extracellular space to (directly or indirectly) stimulate nearby aminergic neurons and, consequently, CRF-expressing targets of their axonal projections in the endocrine hypothalamus. Listed at the right are markers of potentially relevant components of this signaling cascade that have been localized in the requisite regions, either under basal conditions or in response to intravenous IL-1 or endotoxin. Markers that have been co-localized to date are bracketed. It remains to be determined how the others are distributed with respect to the key perivascular (i.e., IL-1R1-expressing) and neuronal (IL-1-sensitive, hypothalamically projecting, and catecholaminergic) cell types.

influences mediated via forebrain inputs, is based on our previous findings that transections of ascending projections from the medulla disrupt IL-1-induced responses in the PVH, and that similar lesions designed to disrupt descending projections from the lamina terminalis are ineffective in this regard (Ericsson et al., 1994). Although we suspect that these latter transections would be apt to disrupt ventral-medial preoptic projections to the $\mathrm{PVH}$, this remains to be determined experimentally. A mediating, as opposed to a merely permissive, influence of ascending aminergic afferents is supported by the starkly differential dependence on the integrity of ascending aminergic inputs of $\mathrm{PVH}$ responses to intravenous IL-1 and foot shock stress, two challenges that provoke patterns of Fos induction in the PVH and medullary aminergic cell groups that are essentially indistinguishable ( $\mathrm{Li}$ et al., 1996). Similar findings have been reported by others using HPA secretory responses as end points (Weidenfeld et al., 1989; Chuluyan et al., 1992).

Thus, the general region of medullary catecholaminergic cell groups and the proximate vasculature contain all essential components of the transduction and paracrine signaling mechanisms we propose (Fig. 8). Challenges to this model are posed by uncertainties about precisely how these components may be distributed, or co-distributed, across cell types in the area. For example, although it has been widely suggested that endothelial cells are the principal seat of perivascular IL-1R1 expression, this has not been established experimentally, and recent evidence has identified perivascular microglia as a major locus of LPS-induced cyclooxygenase-2 expression (Elmquist et al., 1997). Similarly, although the distribution of EP3 receptor message in the medulla suggests overlap with that of IL-1-sensitive catecholaminergic neurons, this, too, remains to be scrutinized directly. This is particularly important, because activation of this receptor is commonly associated with inhibition of adenylate cyclase activity, raising questions of how it might support a stimulatory effect on any aminergic neurons that might express it. It should be recalled that perhaps the best established physiological role of medullary aminergic cells, that of aspects of the $\mathrm{C} 1$ cell group in mediating the baroreceptor inhibition of sympathetic outflow to the peripheral vasculature, is effected via local inhibitory neurons (see Reis et al., 1994), and recent work indicates that such GABAergic neurons are closely interdigitated among aminergic cells in the VLM as well as the NTS (R. K. W. Chan and P. E. Sawchenko, 
unpublished data). Expression of the EP3 receptor by an inhibitory interneuron, with consequent activation of aminergic cells by disinhibition, would be more consistent with the known pharmacology of this receptor subtype than would expression by aminergic neurons themselves.

As discussed elsewhere (Ericsson et al., 1994), initial plasma levels of IL-1 achieved after intravenous injection of IL- $1 \beta$ at the threshold required to elicit IEG responses in hypothalamus and medulla are similar to the peak concentrations seen after systemic treatment with LPS, a model for systemic bacterial infection (Zuckerman et al., 1989). IL-1 titers would be expected to fall precipitously after acute injection (half-life, $\sim 2.9 \mathrm{~min}$; Reimers et al., 1991) but in LPS-treated animals are sustained for hours and reinforced by elevated levels of other proinflammatory cytokines that are capable of independently stimulating HPA output (Naito et al., 1988; Bernardini et al., 1990). Thus, the intravenous IL-1 injection paradigm is relevant to an established animal model of sepsis, at least. In closing, it is important to emphasize that the available evidence is quite clear in indicating that central pathways and mechanisms that are responsive to challenges posed by treatment with individual cytokines, or to more complex immune stimuli, may vary markedly as a function of the nature of the stimulating agent(s), dose, and route of administration. The data provided here simply offer initial support for the mechanism outlined above as a component of the minimum essential circuitry required for the activation of the central limb of the HPA axis by increased circulating IL-1.

\section{REFERENCES}

Abercrombie M (1946) Estimation of nuclear populations from microtome populations from microtome sections. Anat Rec 94:239-247.

Båtshake B, Nilsson C, Sundelin J (1995) Molecular characterization of the mouse prostanoid EP1 receptor gene. Eur J Biochem 231:809-814.

Berkenbosch F, van Oers J, del Rey A, Tilders F, Besedovsky H (1987) Corticotropin-releasing factor-producing neurons in the rat activated by interleukin-1. Science 238:524-526.

Bernardini R, Kamilaris TC, Calogero AE, Johnson EO, Gomez MT, Gold PW, Chrousos GP (1990) Interactions between tumor necrosis factor-alpha, hypothalamic corticotropin-releasing hormone, and adrenocorticotropin secretion in the rat. Endocrinology 126:2876-2881.

Besedovsky H, Sorkin E, Keller M, Müller J (1975) Changes in blood hormone levels during the immune response. Proc Soc Exp Biol Med 150:466-470.

Besedovsky H, del Rey A, Sorkin E, Dinarello CA (1986) Immunoregulatory feedback between interleukin-1 and glucocorticoid hormones. Science 233:652-654.

Bohn MC, Dreyfus CF, Friedman WJ, Markey KA (1987) Glucocorticoid effects on phenylethanolamine $N$-methyltransferase (PNMT) in explants of embryonic rat medulla oblongata. Brain Res 465:257-266.

Breder CD, Smith WL, Raz A, Masferrer J, Seibert K, Needleman P, Saper CB (1992) Distribution and characterization of cyclooxygenase immunoreactivity in the ovine brain. J Comp Neurol 322:409-438.

Chuluyan HE, Saphier D, Rohn WM, Dunn AJ (1992) Noradrenergic innervation of the hypothalamus participates in adrenocortical responses to interleukin-1. Neuroendocrinology 56:106-111.

Coleman RA, Kennedy I, Humphrey PPA, Bunce K, Lumley P (1989) Prostanoids and their receptors. In: Comprehensive medical chemistry: membranes and receptors (Taylor JB, Emmett JC, eds), pp 643-714. Oxford: Pergamon.

Cunningham Jr ET, Wada E, Carter DB, Tracey DE, Battey JF, DeSouza EB (1992) In situ histochemical localization of type 1 interleukin-1 receptor RNA in the central nervous system, pituitary and adrenal gland of the mouse. J Neurosci 12:1101-1114.

Cunningham Jr ET, Miselis RR, Sawchenko PE (1994) The relationship of efferent projections from the area postrema to vagal motor and brain stem catecholamine-containing cell groups: an axonal transport and immunohistochemical study in the rat. Neuroscience 58:635-648.

Dantzer R (1994) How do cytokines say hello to the brain? Neural versus humoral mediation. Eur Cytokine Netw 5:271-273.
Elmquist JK, Saper CB (1996) Activation of neurons projecting to the paraventricular hypothalamic nucleus by intravenous lipopolysaccharide. J Comp Neurol 374:315-331.

Elmquist JK, Breder CD, Sherin JE, Scammell TE, Hickey WF, DeWitt D, Saper CB (1997) Intravenous lipopolysaccharide induces cyclooxygenase 2-like immunoreactivity in rat brain perivascular microglia and meningeal macrophages. J Comp Neurol 381:119-129.

Ericsson A, Sawchenko PE (1993) c-fos-based functional mapping of central pathways subserving effects of interleukin 1 on the hypothalamo-pituitary-adrenal axis. Methods Neurosci 16:155-172.

Ericsson A, Kovács KJ, Sawchenko PE (1994) A functional anatomical analysis of central pathways subserving the effects of interleukin- 1 on stress-related neuroendocrine neurons. J Neurosci 14:897-913.

Ericsson A, Liu C, Hart RP, Sawchenko PE (1995a) Type 1 interleukin-1 receptor in the rat brain: distribution, regulation, and relationship to sites of IL-1-induced cellular activation. J Comp Neurol 361:681-698.

Ericsson A, Ek M, Lindefors N (1995b) Distribution of prostaglandin E2 receptor (EP3 subtype) mRNA containing cells in the rat central nervous system. Soc Neurosci Abstr 21:98.

Ericsson A, Ek M, Wahlstrom I, Kovacs K, Liu C-L, Hart R, Sawchenko PE (1996) Pathways and mechanisms for interleukin-1 mediated regulation of the hypothalamo-pituitary-adrenal axis. In: Stress: molecular genetic and neurobiological advances (McCarty R, Aguilera G, Sabban EL, Kvetnansky R, eds), pp 101-120. New York: Gordon and Breach. Gaykema RPA, Dijkstra I, Tilders FJH (1995) Subdiaphragmatic vagotomy suppresses endotoxin-induced activation of hypothalamic corticotropin-releasing hormone neurons and ACTH secretion. Endocrinology 136:4717-4720.

Goehler LE, Relton J, Maier SF, Watkins LR (1994) Biotinylated interleukin-1 receptor antagonist (IL-1RA) labels paraganglia in the rat liver hilus and hepatic vagus. Soc Neurosci Abstr 20:956.

Harbuz MS, Stephanou A, Sarlis N, Lightman SL (1992) The effects of recombinant human interleukin (IL)- $1 \alpha$, IL- $1 \beta$ or IL-6 on hypothalamo-pituitary-adrenal axis activation. $\mathrm{J}$ Endocrinol 133:349-355.

Hench TR, Kendall EC, Slocumb CH, Polley HF (1949) The effect of a hormone of the adrenal cortex (17-hydroxy-11-dehydrocorticosterone; compound) and of pituitary adrenocorticotropic hormone on rheumatoid arthritis. Staff Proc Mayo Clin 24:181.

Honda A, Sugimoto Y, Namba T, Watabe A, Irie A, Negishi M, Narumiya S, Ichikawa A (1993) Cloning and expression of a cDNA for mouse prostaglandin E receptor EP2 subtype. J Biol Chem 268:7759-7762.

Kapcala LP, He JR, Gao Y, Pieper JO, DeTolla LJ (1996) Subdiaphragmatic vagotomy inhibits intra-abdominal interleukin- $1 \beta$ stimulation of adrenocorticotropin secretion. Brain Res 728:247-254.

Katsuura G, Gottschall PE, Dahl RR, Arimura A (1988) Adrenocorticotropin release induced by intracerebroventricular injection of recombinant human interleukin-1 in rats: Possible involvement of prostaglandin. Endocrinology 122:1773-1779.

Li H-Y, Ericsson A, Sawchenko PE (1996) Distinct mechanisms underlie activation of hypothalamic neurosecretory neurons and their medullary catecholaminergic afferents in categorically different stress paradigms. Proc Natl Acad Sci USA 93:2359-2364.

Matsumura K, Watanabe Y, Imai-Matsumura K, Connolly M, Koyama Y, Onoe H, Watanabe Y (1992) Mapping of prostaglandin E2 binding sites in rat brain using quantitative autoradiography. Brain Res 581:292-298.

Morgan JL, Curran T (1991) Stimulus-transcription coupling in the nervous system: involvement of the inducible proto-oncogenes fos and jun. Annu Rev Neurosci 14:421-451.

Naito Y, Fukata J, Tominaga T, Nakai Y, Tamai S, Mori K, Imura H (1988) Interleukin-6 stimulates the secretion of adrenocorticotropic hormone in conscious, freely-moving rats. Biochem Biophys Res Commun 155:1459-1463.

Nakano K, Okugawa K, Hayashi H, Abe S, Sohmura Y, Tsuboi T (1988) Establishment of dye-uptake method (A375 assay) for quantitative measurement of IL-1: correlation with LAF assay. Dev Biol 69:93-101.

Nijima A (1992) The afferent discharges from sensors for interleukin $1 \beta$ in the hepato-portal system in the rat. J Physiol (Lond.) 446:236P.

Nishigaki N, Negishi M, Honda A, Sugimoto Y, Namba T, Narumiya S, Ichikawa A (1995) Identification of prostaglandin E receptor "EP2" cloned from mastocytoma cells as EP4 subtype. FEBS Lett 364:339-341. 
Reimers J, Wogensen LD, Welinder B, Hejnaes KR, Poulsen SS, Nilsson P, Nerup J (1991) The pharmacokinetics, distribution and degradation of human recombinant interleukin- $1 \beta$ in normal rats. Scand J Immunol 34:597-617.

Reis DJ, Golanov EV, Ruggiero DA, Sun MK (1994) Sympathoexcitatory neurons of the rostral ventrolateral medulla are oxygen sensors and essential elements in the tonic and reflex control of the systemic and cerebral circulations. J Hypertens 12:S159-S180.

Rivest S, Rivier C (1991) Influence of the paraventricular nucleus of the hypothalamus in the alteration of neuroendocrine functions induced by intermittent footshock or interleukin. Endocrinology 129:2049-2057.

Rivier C, Rivest S (1993) Mechanisms mediating the effects of cytokines on neuroendocrine functions in the rat. Ciba Found Symp 172:204-220.

Rotondo D, Abul HT, Milton AS, Davidson J (1988) Pyrogenic immunomodulators increase the levels of prostaglandin $\mathrm{E} 2$ in the blood simultaneously with the onset of fever. Eur J Pharmacol 154:145-152.

Sapolsky R, Rivier C, Yamamoto G, Plotsky P, Vale W (1987) Interleukin-1 stimulates the secretion of hypothalamic corticotropinreleasing factor. Science 238:522-524.

Sawchenko PE, Gold RM (1981) Effects of complete subdiaphragmatic vs. selective gastric vagotomy on hypothalamic hyperphagia and obesity. Physiol Behav 26:281-292.

Sawchenko PE, Cunningham Jr ET, Mortrud MT, Pfeiffer SW, Gerfen CR (1990) Phaseolus vulgaris-leucoagglutinin (PHA-L) anterograde axonal transport technique. Methods Neurosci 3:247-260.

Scammell TE, Elmquist JK, Griffin JD, Saper CB (1996) Ventromedial preoptic prostaglandin E2 activates fever-producing autonomic pathways. J Neurosci 16:6246-6254.

Shu S, Ju G, Fan L (1988) The glucose oxidase-DAB-nickel method in peroxidase histochemistry of the nervous system. Neurosci Lett 85:169-171.

Simmons DM, Arriza JL, Swanson LW (1989) A complete protocol for in situ hybridization of messenger RNAs in brain and other tissues with radiolabeled single-stranded RNA probes. J Histotechnol 12:169-181.

Sternberg EM, Wilder, RL (1993) Corticosteroids. In: Arthritis and allied conditions: a textbook of rheumatology, Ed 12 (McCarthy DJ, Koopman DJ, eds), pp 665-682. Philadelphia: Lea \& Febiger.

Sugimoto Y, Namba T, Honda A, Hayashi Y, Negishi M, Ichikawa A, Narumiya S (1992) Cloning and expression of a cDNA for mouse prostaglandin E receptor EP3 subtype. J Biol Chem 267:6463-6466.

Sugimoto Y, Shigemoto R, Namba T, Negishi M, Mizuno N, Narumiya S, Ichikawa A (1994) Distribution of the messenger RNA for the prostaglandin E receptor subtype EP3 in the mouse nervous system. Neuroscience 62:919-928.

Swanson LW, Kuypers HGJM (1980) The paraventricular nucleus of the hypothalamus: cytoarchitectonic subdivisions and the organization of projections to the pituitary, dorsal vagal complex and spinal cord as demonstrated by retrograde fluorescence double labeling methods. J Comp Neurol 194:555-575.

Takeuchi K, Abe T, Takahashi N, Abe K (1993) Molecular cloning and intrarenal localization of rat prostaglandin E2 receptor EP3 subtype. Biochem Biophys Res Commun 194:885-891.

Tilders FJ, DeRijk RH, Van Dam AM, Vincent VA, Schotanus K, Persoons JH (1994) Activation of the hypothalamus-pituitary-adrenal axis by bacterial endotoxins: routes and intermediate signals. Psychoneuroendocrinology 19:209-232.

Van Dam A-M, Brouns M, Man-A-Hing W, Berkenbosch F (1993) Immunocytochemical detection of prostaglandin $E_{2}$ in microvasculature and in neurons of rat brain after administration of bacterial endotoxin. Brain Res 613:331-336.

Wan W, Wetmore L, Sorensen CM, Greenberg AH, Nance DM (1994) Neural and biochemical mediators of endotoxin and stress-induced c-fos expression in the rat brain. Brain Res Bull 34:7-14.

Watabe A, Sugimoto Y, Honda A, Irie A, Namba T, Negishi M, Ito S, Narumiya S, Ichikawa A (1993) Cloning and expression of cDNA for a mouse EP1 subtype of prostaglandin E receptor. J Biol Chem 268:20175-20178.

Watanabe T, Morimoto A, Sakata Y, Murakami N (1990) ACTH response induced by interleukin-1 is mediated by CRF secretion stimulated by hypothalamic PGE. Experientia 46:481-484.

Watanobe H, Nasushita R, Takebe K (1995) A study on the role of circulating prostaglandin E2 in the adrenocorticotropin response to intravenous administration of interleukin-1beta in the rat. Neuroendocrinology 62:596-600.

Watkins LR, Maier SF, Goehler LE (1995) Cytokine-to-brain communication: a review and analysis of alternative mechanisms. Life Sci 57:1011-1026.

Weidenfeld J, Abramsky O, Ovadia H (1989) Evidence for the involvement of the central adrenergic system in interleukin 1-induced adrenocortical response. Neuropharmacology 28:1411-1414.

Wick G, Hu Y, Schwartz S, Kroemer G (1993) Immunoendocrine communication via the hypothalamo-pituitary-adrenal axis in autoimmune diseases. Endocr Rev 14:539-563.

Wong M-L, Licinio J (1994) Localization of interleukin-1 type 1 receptor mRNA in rat brain. Neuroimmunomodulation 1:110-115.

Yabuuchi K, Minami M, Katsumata S, Satoh M (1994) Localization of type I interleukin-1 receptor mRNA in the rat brain. Mol Brain Res 27:27-36.

Zuckerman SH, Shellhaas J, Butler LD (1989) Differential regulation of lipopolysaccharide-induced interleukin 1 and tumor necrosis factor synthesis: effects of endogenous and exogenous glucocorticoids and the role of the pituitary-adrenal axis. Eur J Immunol 19:301-305. 